\title{
FORMULATION AND EVALUATION OF NANOSUSPENSION OF VALSARTAN
}

\author{
MANISHAANJANE*, SHIKHA AGRAWAL, AMREEN KHAN \\ Department of Pharmaceutics, Swami Vivekanand College of Pharmacy, Indore 452020, Madhya Pradesh, India \\ Email: anjanemanisha92@gmail.com
}

Received: 27 Dec 2017, Revised and Accepted: 05 Feb 2018

\begin{abstract}
Objective: The objective of the present research work was to formulate and evaluate Valsartan nanosuspension by nanoprecipitation ultra sonication method using different polymers to enhance solubility and bioavailability of the poorly water-soluble drug.

Methods: Formulation of nanosuspension of valsartan by nanoprecipitation technique was used. The nanosuspension formulations were prepared using different polymers such as hydroxyl propyl methyl cellulose E50, polyvinyl pyrollidone k-30, polyethene glycol 6000 and sodium lauryl sulphate was used as the surfactant.

Results: The formulation of nanosuspension was formed clear and no sedimentation was seen on further shaking. The nanosuspension formulations were Valsatan shows maximum solubility in HPMC as a non-volatile solvent. All the Preformulation parameters were evaluated such as organoleptic characterization of drug sample, melting point, $\mathrm{pH}$, partition coefficient, identification of drug samples by using UV spectroscopy and FTIR analytical method, preparation of calibration curves, solubility studies of drug sample like qualitative, quantitative and pH dependent solubility of drug in different pH buffer solution. The viscosity of the dispersion medium was more in F10.895 mPa-s and F2 $0.894 \mathrm{mPa}$-s than the other formulations. The particle size distribution of the nanosuspension with zeta potential found to be negative mv. Fourier transform infrared spectroscopy indicated that there was no possible interaction between drug and polymer.
\end{abstract}

Conclusion: From this study, it was concluded that in recent advances in novel drug delivery system aims to enhance safety and efficacy of drug molecule by formulating a convenient dosage form for administration and to achieve better patient compliance, one such approach is nanosuspension.

Keywords: Nanosuspension, Ultrasonocation, Nanoprecipitation, Solubility, Valsartan, Antihypertensive

(c) 2018 The Authors. Published by Innovare Academic Sciences Pvt Ltd. This is an open access article under the CC BY license (http://creativecommons.org/licenses/by/4.0/) DOI: http://dx.doi.org/10.22159/ijcpr.2018v10i2.25874

\section{INTRODUCTION}

The objective of present research work is to enhance the aqueous solubility of the poorly water-soluble drug valsartan by using the nanosuspension technique by the simple and cost-effective method by using suitable solvents and stabilizers in various concentration [1]. Nanosuspensions consist of the weakly water-soluble drug with no matrix material suspended in the dispersion. These can be used to enhance the solubility of drugs that are poorly soluble in water. As a result of increased solubility, the rate of flooding of the active compound increases and the maximum plasma level is reached faster. This approach is helpful for molecules with poor solubility, poor permeability or both, which acquire a significant dispute for the formulators [2].

Valsartan is a new potent and orally active antihypertensive drug which selectivity act as angiotensin II antagonist acting on the AT1 receptor subtype. It is indicated for hypertension, heart failure and post-myocardial infarction [3]. The major problem in oral drug formulations is low and erratic bioavailability, which mainly results from poor aqueous solubility. The drug is having low aqueous solubility of about $0.0213 \mathrm{mg} / \mathrm{ml}$. The drug is rapidly absorbed after oral administration having bioavailability is $23 \%$ [4]. This compound belongs to the class of organic compounds known as biphenyl tetrazoles and derivatives. These are organic compounds containing a biphenyl attached to a tetrazole. A carbon atom of the biphenyl moiety is boned to a carbon or the nitrogen atom of the tetrazole moiety. Other techniques are like liposomes, emulsions, microemulsion, solid dispersion and inclusion complexation using cyclodextrins show sensible achiever, but they lack in universal applicability to all drugs [5]. These techniques are not applicable for those drugs which are not soluble in aqueous and organic solvents. .Recent advances in novel drug delivery system aims to enhance safety and efficacy of drug molecule by formulating a convenient dosage form for administration and to achieve better patient compliance, one such approach is nanosuspension [6].

\section{MATERIALS AND METHODS}

\section{Materials}

Drug Valsartan was obtained as a gift sample from Cipla, Pithampur and hetero drugs, Hyderabad respectively. Hydroxypropyl methylcellulose was procured from LobaChemie Laboratory. Polyvinyl pyrrolidone k-30 and sodium lauryl sulphate was obtained from Hemedia. All other chemicals used in this study were of analytical grade.

\section{Methods}

\section{Preformulation studies}

Preformulation involves the application of biopharmaceutical principles to the physicochemical parameters of drug substance are characterized with the goal of designing optimum drug delivery system.

\section{Organoleptic properties}

The pure drug sample was studied for their organoleptic properties like colour, odour, taste and crystallinity.

\section{Melting point}

In this method a small amount of drug was filled in a capillary tube open both the ends and it was placed along with thermometer in melting point apparatus (BTI-34 melting point apparatus, Mumbai, India).

\section{pH value}

$0.1 \%$ solution was prepared in distilled water using the minimum amount of methanol and the $\mathrm{pH}$ of the solution was measured at $25 \pm 1^{\circ} \mathrm{C}$ using $\mathrm{pH}$ meter (Global instruments $\mathrm{pH}$ meter, Delhi).

\section{Partition coefficient}

The partition coefficient study of valsartan was performed using noctanol as the oil phase and phosphate buffer $\mathrm{pH} 7.4$ as the aqueous 
phase. The two phases were mixed in equal quantities $(50 \mathrm{ml})$ by adding $20 \mathrm{mg}$ of drug in a separating funnel and was saturated with each other at room temperature for $24 \mathrm{~h}$. The saturated phases were separated by centrifugation. The two phases were separated and then analysed for respective drug contents. The partition coefficient measured by the given formula:

$$
\frac{\mathrm{K}_{0 / \mathrm{w}}=\text { Concentaration of drug in oil phase }}{\text { Concentration of drug in aqueous phase }}
$$

\section{Determination of $\lambda_{\max }$ by UV Spectrophotometer}

The identification of drug was done by UV spectrophotometric by a simple quantitative method using Shimadzu Spectrophotometer UV1800 (Shimadzu Corp., Japan).

$50 \mathrm{mg}$ of drug Valsartan has weighed accurately and transferred into a $50 \mathrm{ml}$ volumetric flask and dissolved in methanol. The flask was shaken and volume was made up to the mark with methanol to give a solution of $1000 \mu \mathrm{g} / \mathrm{ml}$. From this solution, $10 \mathrm{ml}$ of solution was pipetted out and placed into $100 \mathrm{ml}$ volumetric flask. The volume was made up to the mark with methanol to give a $100 \mu \mathrm{g} / \mathrm{ml}$. A dilution of $20 \mu \mathrm{g} / \mathrm{ml}$ concentration was made from the above stock solution with the methanol and the resulting solution was scanned between the wavelength of $200 \mathrm{~nm}$ to $400 \mathrm{~nm}$.

\section{Preparation of calibration curve of valsartan}

A standard stock solution of valsartan was prepared by dissolving $100 \mathrm{mg}$ of drug in $100 \mathrm{ml}$ of methanol $(1000 \mu \mathrm{g} / \mathrm{ml})$. From the above stock solution, $10 \mathrm{ml}$ was taken and diluted up to $100 \mathrm{ml}$ in $0.1 \mathrm{~N}$ $\mathrm{NaOH}(100 \mu \mathrm{g} / \mathrm{ml})$. From the above solution $0.1,0.2,0.3,0.4,0.5,0.6$, $0.7,0.8,0.9$ and $1 \mathrm{ml}$ was taken and diluted up to $10 \mathrm{ml}$ with methanol to get series of solutions in concentration in range from 1 to $10 \mu \mathrm{g} / \mathrm{ml}$ of valsartan. Absorbance was noted using UV-VIS Spectrophotometer at $\lambda_{\max }$ of $249 \mathrm{~nm}$ against a blank $(0.1 \mathrm{~N} \mathrm{NaOH})$.

\section{Solubility determination of valsartan}

Qualitative solubility analysis: $10 \mathrm{mg}$ drug in $10 \mathrm{ml}$ solvent (aqueous/non-aqueous) taken in a conical flask. Different solvents were used for the solubility determination to determine the solubility of the drug. After shaking, the sample was examined for the presence of any undissolved suspended particles and clarity.

Quantitative solubility analysis: Dissolving excess amount of solute in $10 \mathrm{ml}$ solvent in conical flask till a saturated solution was obtained. Different solvents were used for solubility determination like water, acetone, methanol, ethanol, for determination of solute dissolved in each solvent. These conical flasks were stoppered and agitated in thermostatically controlled orbital shaker at $25 \pm 1{ }^{\circ} \mathrm{C}$. After $24 \mathrm{~h}$ equilibrium was attained and the sample was filtered through Whatman filter paper (No.1). The sample was analysed after dilution for the concentration of drug dissolved using UV-VIS spectrophotometer.

\section{pH-dependent solubility}

The solubility determination of valsartan was carried out in different $\mathrm{pH}$ solvents. The phosphate buffer of $\mathrm{pH} 1.2$ to 10 was prepared in freshly boiled and cooled distilled water, and their $\mathrm{pH}$ was adjusted $( \pm 0.5)$. These solutions were filtered through Whatman filter paper (No.1) and kept in tightly closed glass bottles.

The drug was added in excess quantity to a series of screwcapped 15 ml glass vials containing $10 \mathrm{ml}$ of phosphate buffer solutions of varying $\mathrm{pH}$ such as $1.2,2.2,4.6,5.8,7.4,8,9$ and 10 until a saturated solution was obtained. The vials were mechanically shaken at room temperature for $24 \mathrm{~h}$, in thermostatically controlled orbital shaker at $25 \pm 1{ }^{\circ} \mathrm{C}$. These suspensions were filtered through Whatman filter paper. Aliquots of the filtrate obtained were diluted with distilled water and analysed using UV spectrophotometer at $249 \mathrm{~nm}$ against blank in case of valsartan.

\begin{tabular}{|c|c|c|c|}
\hline S. No. & Parameters & Observation & Result \\
\hline 1. & Organoleptic properties & Colour, odour, taste and crystallinity & $\begin{array}{l}\text { White to off-white crystalline powder, } \\
\text { odourless, tasteless }\end{array}$ \\
\hline 2. & Melting point & $116-117^{\circ} \mathrm{C}$ & $116 \pm 2^{\circ} \mathrm{C}$ \\
\hline 3. & $\mathrm{pH}$ value & Found to be weakly acidic in nature & 3.5 \\
\hline 4. & Partition coefficient & Lipophillic in nature & 3.8 \\
\hline 5. & $\begin{array}{l}\text { Determination of max by UV } \\
\text { spectrophotometer }\end{array}$ & $\begin{array}{l}\text { Valsartan by UV analysis was carried out in } 0.1 \mathrm{~N} \mathrm{NaoH} \\
\text { as the drug was completely soluble in } \mathrm{NaOH} \text {. }\end{array}$ & $\begin{array}{l}\text { The spectrum was found to be maximum at } \\
\lambda_{\max } 249 \mathrm{~nm} .\end{array}$ \\
\hline 6. & $\begin{array}{l}\text { Preparation of calibration } \\
\text { curve of valsartan }\end{array}$ & $\begin{array}{l}\text { Absorbance was noted using UV spectrophotometer of } \\
\text { different concentration }\end{array}$ & Shows linear standard curve of valsartan \\
\hline 7. & Solubility studies & $\begin{array}{l}\text { Qualitative solubility in which valsartan was soluble in } \\
\text { methanol, ethanol, acetone, dichloromethane, } 0.1 \mathrm{~N} \\
\mathrm{NaOH}, \mathrm{pH}(7.4) \text { phosphate buffer. Quantitatively drug was } \\
\text { more soluble in ethanol and methanol. }\end{array}$ & $\begin{array}{l}\text { Valsartan was freely soluble in methanol and } \\
\text { ethanol. Quantitatively more soluble in } \\
\text { methanol }(2.76 \mathrm{~g} / \mathrm{ml}) \text { and ethanol }(2.15 \mathrm{~g} / \mathrm{ml}) \text {. }\end{array}$ \\
\hline 8. & pH-dependent solubility & $\begin{array}{l}\text { Valsartan was carried out in different } \mathrm{pH} \text { solvents }(\mathrm{pH} 1.2 \\
\text { to } 10) .\end{array}$ & $\begin{array}{l}\text { The solubility of valsartan in water was } \\
0.0213 \mathrm{mg} / \mathrm{ml} \text { and in pH } 10 \text { was } 1.150 \mathrm{mg} / \mathrm{ml} \\
\text { and hence solubility of valsartan in } \mathrm{pH} 10 \text { was } \\
\text { increased by } 54 \text { times. }\end{array}$ \\
\hline
\end{tabular}

Table1: Preformulation studies of valsartan

\begin{tabular}{|c|c|c|c|c|c|}
\hline Formulation code & Drug & $\begin{array}{l}\text { Polymer } \\
\text { HPMCE50PVPK30PEG6000 }\end{array}$ & Surfactant (SLS) & Methanol & Water \\
\hline F1 & $10 \mathrm{mg}$ & $20 \mathrm{mg}$ & 0.03 & $10 \mathrm{ml}$ & $50 \mathrm{ml}$ \\
\hline F2 & $10 \mathrm{mg}$ & $40 \mathrm{mg}$ & 0.02 & $10 \mathrm{ml}$ & $50 \mathrm{ml}$ \\
\hline F3 & $10 \mathrm{mg}$ & $60 \mathrm{mg}$ & 0.01 & $10 \mathrm{ml}$ & $50 \mathrm{ml}$ \\
\hline $\mathrm{F} 4$ & $10 \mathrm{mg}$ & $20 \mathrm{mg}$ & 0.03 & $10 \mathrm{ml}$ & $50 \mathrm{ml}$ \\
\hline F5 & $10 \mathrm{mg}$ & $40 \mathrm{mg}$ & 0.02 & $10 \mathrm{ml}$ & $50 \mathrm{ml}$ \\
\hline F6 & $10 \mathrm{mg}$ & $60 \mathrm{mg}$ & 0.01 & $10 \mathrm{ml}$ & $50 \mathrm{ml}$ \\
\hline F7 & $10 \mathrm{mg}$ & $20 \mathrm{mg}$ & 0.03 & $10 \mathrm{ml}$ & $50 \mathrm{ml}$ \\
\hline F8 & $10 \mathrm{mg}$ & $40 \mathrm{mg}$ & 0.02 & $10 \mathrm{ml}$ & $50 \mathrm{ml}$ \\
\hline F9 & $10 \mathrm{mg}$ & $60 \mathrm{mg}$ & 0.01 & $10 \mathrm{ml}$ & $50 \mathrm{ml}$ \\
\hline
\end{tabular}

Table 2: Composition of optimized formulations of nanosuspension of valsartan 


\section{Preparation of nanosuspension of valsartan}

The Valsartan nanosuspension was prepared by nanoprecipitation method. Firstly, $10 \mathrm{mg}$ of drug is dissolved in a $50 \mathrm{ml}$ of methanol. Then kept on a magnetic stirrer and this solution is then mixed with a miscible antisolvent system in the presence of surfactants. Rapid addition of drug solution into the antisolvent leads to sudden supersaturation of drug in the mixed solution forms ultrafine drug solids.

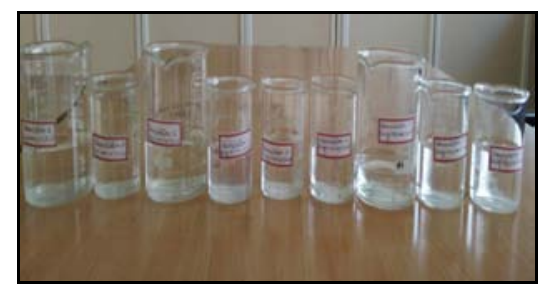

Fig. 1: Preparation of nanosuspension formulations

\section{Characterization of optimized nanosuspension}

\section{Drug content}

Drug content was determined by UV-Visible spectrophotometer at $249 \mathrm{~nm}$. About $1 \mathrm{ml}$ of nanosuspension preparation was taken and diluted with $0.1 \mathrm{~N} \mathrm{Hcl}$.

\section{Redispersibility}

Nanosuspension stored in vials was determined by titling the vial bottle up and down with hand till the sediment was uniformly dispersed in the aqueous phase and the no. of times tilted was noted.

\section{Viscosity measurement}

The viscosity of lipid-based formulations of several compositions can be measured at different shear rates at different temperatures using Brookfield type rotatory viscometer.

The sample room of the instrument must be maintained at $37 \% \mathrm{C}$ by a thermo bath and the samples, for the measurement are to be immersed in it and found viscosity of the formulations.

\section{Measurement of particle size and size distribution}

The mean particle size and the width of particle size distribution called polydispersity index are determined by Photon Correlation Spectroscopy (PCS). Particle size and polydispersity index (PI) govern the saturated solubility; dissolution velocity and biological performance. The prepared nanosuspension of $100 \mu \mathrm{l}$ was diluted to $5 \mathrm{ml}$ with double distilled water and diluted dispersion was measured using Malvern zetasizer.

\section{Zeta potential}

For Zeta potential determination samples of formulations were diluted with water and placed in the electrophoretic cell. Each sample was measured 3 times at $25 \% \mathrm{C}$ and average values were employed for measuring the response

\section{Dissolution velocity and saturation solubility study}

Adding the excess amount of sample to distilled water $(2 \mathrm{ml})$ and the samples were subjected to shaking in screw-capped vials for $24 \mathrm{~h}$. The sample was further taken in test tubes and centrifuged at 1000 rpm for $10 \mathrm{~min}$. after the sample was filtered through a 0.22 micrometer membrane filter and the filtrate was diluted appropriately with distilled water and drug content was estimated in UV spectroscopy.

\section{Fourier transform infrared spectroscopy}

The drug-polymer compatibility was ascertained by subjecting the drug and polymer to Fourier transform infrared spectrometric study using FTIR-affinity-1S-Shimadzu, The samples were scanned in the spectral region between 4000 and $400 \mathrm{~cm}^{-1}$. The solid material was placed onto the small crystal area, then the pressure arm was positioned over the crystal/sample area. Force was applied to the sample, pushing it onto the diamond surface. Transmittance was measured from wave number $4000 \mathrm{~cm}^{-1}$ to $400 \mathrm{~cm}^{-1}$.

\section{RESULTS AND DISCUSSION}

\section{A. Drug content}

Drug content of various formulations are shown below in table1. The percentage of drug content in formulation 1 and formulation 2 was more as $96.677 \%$ and $97.543 \%$.

Table 3: Drug content of various formulations

\begin{tabular}{lll}
\hline S. No. & Formulation code & \% Drug content \\
\hline 1. & F1 & 96.677 \\
2. & F2 & 97.543 \\
3. & F3 & 94.432 \\
4. & F4 & 95.667 \\
5. & F5 & 94.632 \\
6. & F6 & 90.345 \\
7. & F7 & 96.535 \\
8. & F8 & 92.675 \\
9. & F9 & 94.576 \\
\hline
\end{tabular}

\section{B. Redispersibility}

The redispersibility of various formulations was shown in table 2 . The F2 and F1 formulation was best among all formulations. On shaking it may be easily redispersed.

\section{Viscosity measurement}

The viscosity measurement of different formulations was shown in table 3. The F2 shows $0.894 \mathrm{~m}$ Pa-s and F1 shows $0.895 \mathrm{~m} \mathrm{Pa-s}$ respectively.

Table 4: Redispersibility of various formulations

\begin{tabular}{ll}
\hline Formulation code & Redispersibility \\
\hline F1 & Fast \\
F2 & Very Fast \\
F3 & Medium \\
F4 & Fast \\
F5 & Fast \\
F6 & Fast \\
F7 & Medium \\
F8 & Fast \\
F9 & Fast \\
\hline
\end{tabular}


Table 5: Viscosity measurement of different formulations

\begin{tabular}{lll}
\hline S. No. & Formulation code & The viscosity of the dispersion medium \\
\hline 1. & F1 & $0.895 \mathrm{mPa}-\mathrm{s}$ \\
2. & F2 & $0.894 \mathrm{mPa}-\mathrm{s}$ \\
3. & F3 & $0.892 \mathrm{mPa}-\mathrm{s}$ \\
4. & F4 & $0.890 \mathrm{mPa}-\mathrm{s}$ \\
5. & F5 & $0.879 \mathrm{mPa}-\mathrm{s}$ \\
6. & F6 & $0.875 \mathrm{mPa}-\mathrm{s}$ \\
7. & F7 & $0.874 \mathrm{mPa}-\mathrm{s}$ \\
8. & F8 & $0.872 \mathrm{mpa}-\mathrm{s}$ \\
9. & F9 & $0.870 \mathrm{mPa}-\mathrm{s}$ \\
\hline
\end{tabular}

\section{Measurement of particle size and particle size distribution}

The particle size and polydispersity index of formulation $1^{\text {st }}$ and $2^{\text {nd }}$ was shown in fig. 9 and fig 10. The particle size and the Polydispersity Index (PI) of the former drug particles were measured immediately after precipitation by dynamic laser light scattering (Zetasizer Ver. 6.11Malvern). The polydispersity index of $\mathrm{F} 1$ and F2 was found to be in the range of 4.194 and 230.81 .

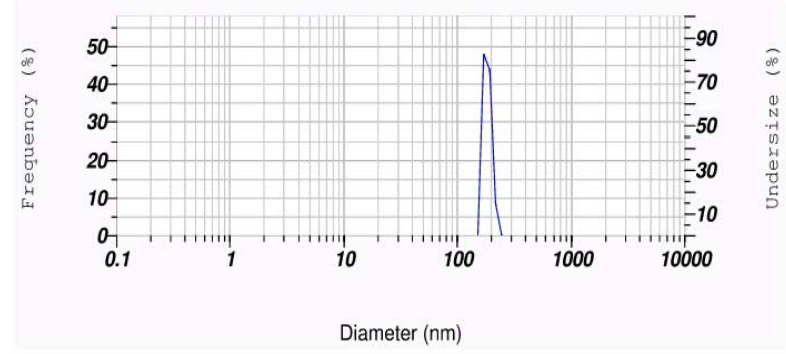

Fig. 2: Particle size and polydispersibility index of formulation1

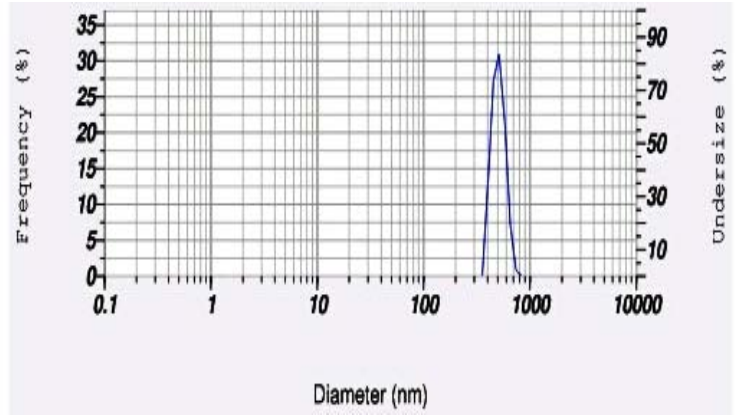

Fig. 1: Particle size and polydispersibility index of formulation2

\section{E. Particle charge (Zeta potential)}

The particle charge of formulation 1 and formulation 2 shows in fig. 2 and fig. 3. The zeta potential of the nanoparticles was found to be negative which may be due to the presence of terminal carboxylic groups. High potential values should be achieved to ensure a highenergy barrier and favour a good stability.

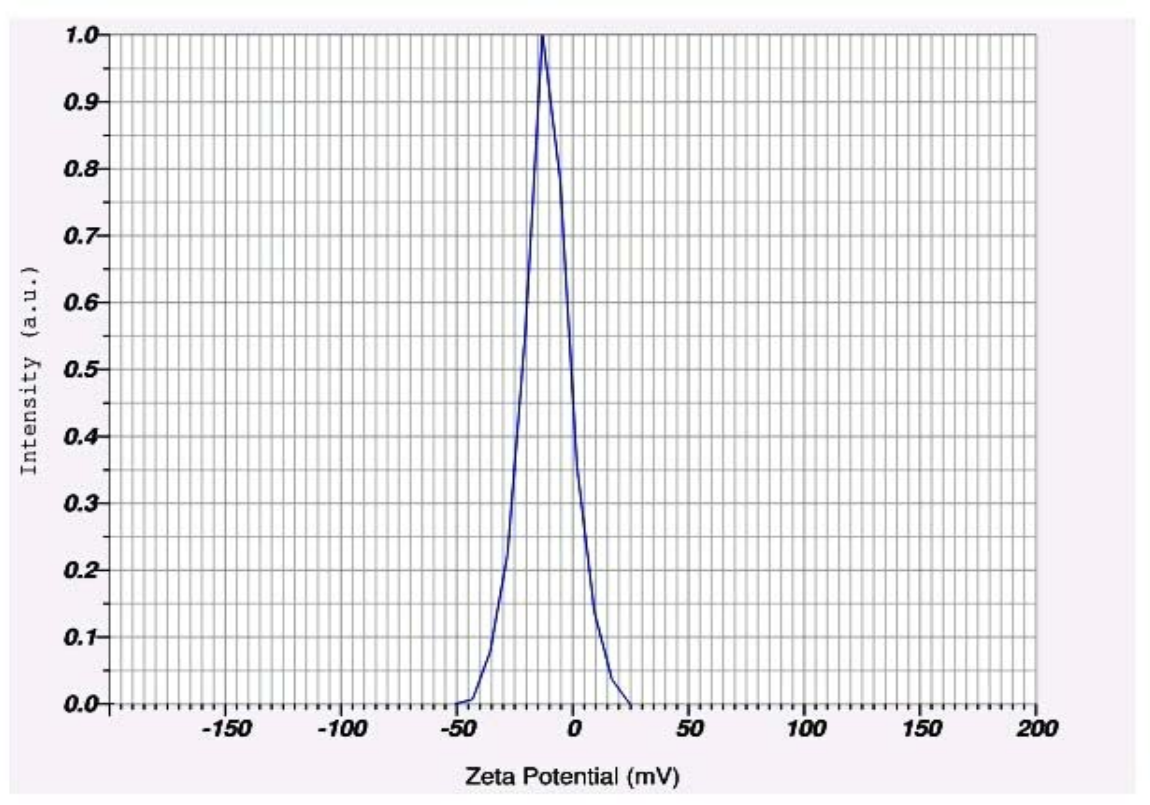

Fig. 2: Zeta potential of formulation1

\section{F. Dissolution velocity and saturation solubility}

The saturation solubility of different formulations was shown in table 4. Saturation solubility of an optimized batch of Nanosuspension was found to be $0.941 \mathrm{mg} / \mathrm{ml}$ and $0.772 \mathrm{mg} / \mathrm{ml}$ respectively. The improvement in saturation solubility is due to a reduction in particle size and subsequent increase in surface area.

So, it can be assumed that this increase in saturation solubility may improve bioavailability. 


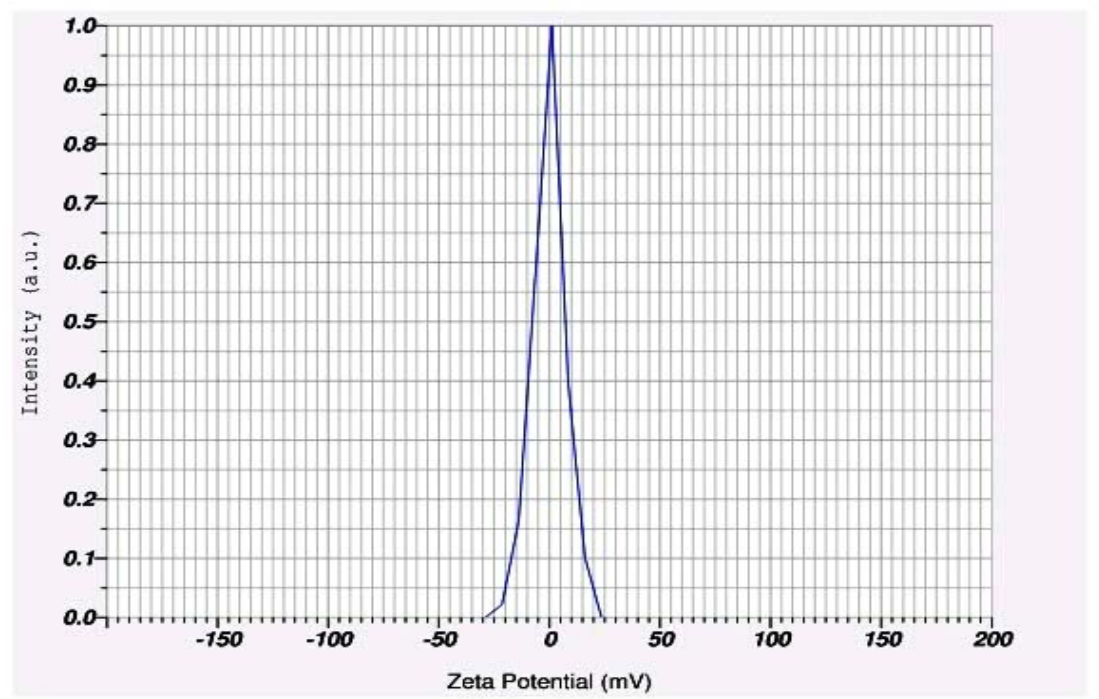

Fig. 3: Zeta potential of formulation2

Table 6: Saturation solubility of different formulation

\begin{tabular}{lll}
\hline S. No. & Formulation code & Saturation solubility in water $\mathbf{~ m g / m l ~}$ \\
\hline 1. & F1 & 0.772 \\
2. & F2 & 0.941 \\
3. & F3 & 0.620 \\
4. & F4 & 0.537 \\
5. & F5 & 0.526 \\
6. & F6 & 0.442 \\
7. & F7 & 0.507 \\
8. & F8 & 0.432 \\
9. & F9 & 0.650 \\
\hline
\end{tabular}

\section{G. FT-IR}

The FTIR spectra of Valsartan with HPMC and FTIR spectra of Formulation1 shows in fig 3 and fig 4 . The precipitated nanoparticles were comparable and the peaks of Valsartan in the physical mixture are of lower intensity than pure drug. The characteristic peak of $\mathrm{N}-\mathrm{H}$ amide stretching, aromatic cyclic enes, $\mathrm{CO}$ group of acid, $\mathrm{C}=\mathrm{C}$ aromatic, Carbonyl group, hydroxyl group, $\mathrm{C}-\mathrm{H}$ bending (aromatic), C-C bending $\mathrm{cm}-1$ which respectively were found to be intact in the physical mixture as well as the formulation which indicates the absence of HPMC and drug interactions.

Very less stretching or broadening of peaks of the drug was observed in mixture form.

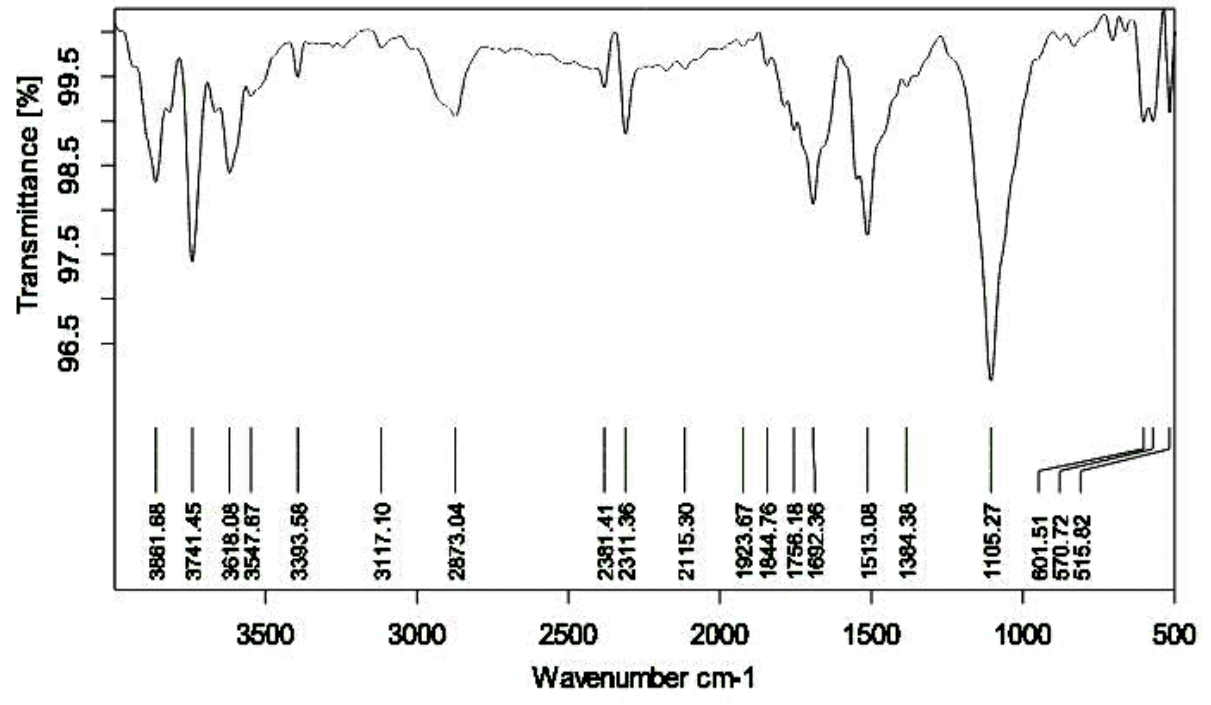

Fig. 4: FTIR Spectra of drug valsartan with polymer HPMC 


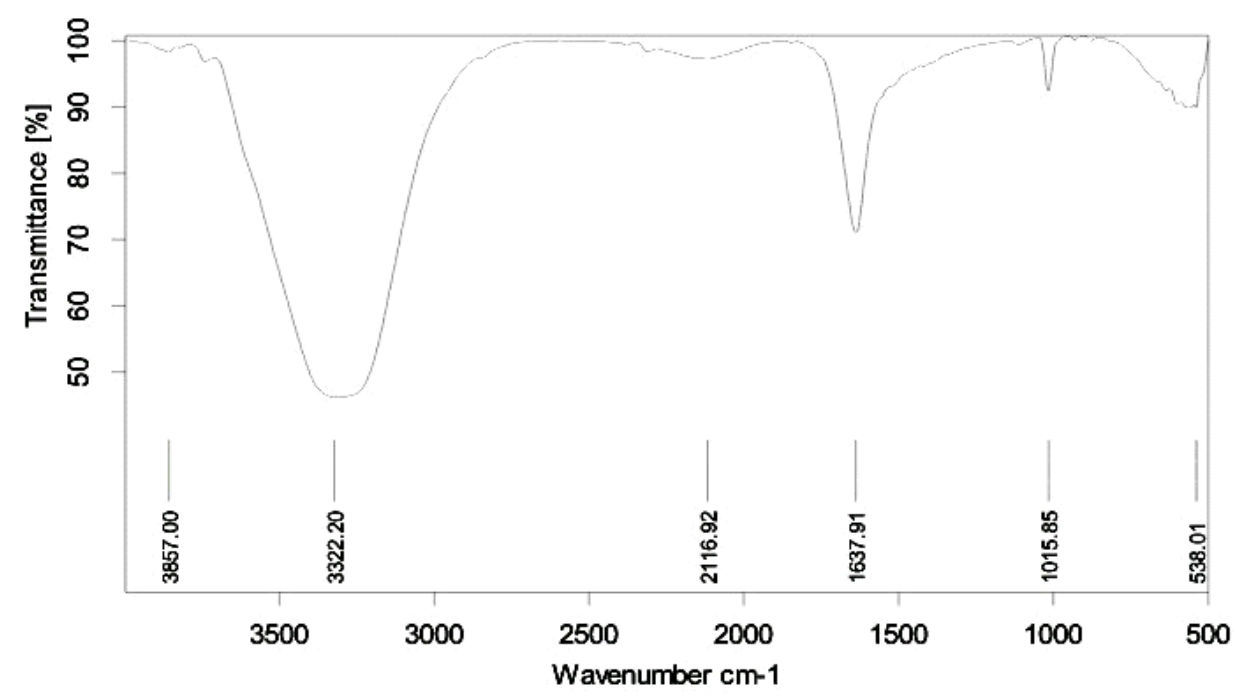

Fig.5: FTIR spectra of formulation1

\section{Stability of formulated nanosuspension}

The particle size of the formulations after 4 mo was observed. The formulations at $4{ }^{\circ} \mathrm{C}$ remained stable, whereas that at room temperature showed a slight increase in particle size. The stability studies of formulation F1 and F2 had been performed. A loose, thin layer of sediment was observed when nanosuspension was stored at room temperature for $1 \mathrm{mo}$. However, the sediment disappeared with slight handshaking. The average particle diameter was found to be $106.3 \mathrm{~nm}$ and $105.3 \mathrm{~nm}$ when the sample was stored at room temperature.

Table 7: Stability of formulated nanosuspension

\begin{tabular}{|c|c|c|c|}
\hline Formulation code & Storage temperature conditions & Initial particle size & Particle size after $4 \mathrm{mo}$ \\
\hline \multirow[t]{2}{*}{ F1 } & $4^{\circ} \mathrm{C}$ & 108.4 & 104.4 \\
\hline & Room temp. & & 106.3 \\
\hline \multirow[t]{2}{*}{$\mathrm{F} 2$} & $4^{\circ} \mathrm{C}$ & 105.6 & 102.5 \\
\hline & Room temp. & & 105.3 \\
\hline
\end{tabular}

\section{CONCLUSION}

It was concluded that the nanoprecipitation with ultrasonication have potential to formulate homogeneous nanosuspensions with uniform sized stable nanoparticles of valsartan. It is a rapid and easy technique and nanoparticles were formed spontaneously. Nanoparticles were characterized by particle size distribution, zeta potential analysis, Fourier transform infrared spectroscopy. This method can be used to improve the therapeutic efficacy of poorly soluble drugs. The preparations were found to physically stable with HPMC as a stabiliser.

\section{ACKNOWLEDGEMENT}

I am grateful to Dr. P. K. Dubey (Principle of, SVCP Indore) for providing all the research facilities. I am highly thankful to Dr. Shikha Agrawal for all the support and completion for this work.

\section{AUTHORS CONTRIBUTIONS}

All the author have contributed equally

\section{CONFLICT OF INTERESTS}

The authors declare that they have no conflict of interest

\section{REFERENCES}

1. Mayuri Yadav, Shashikanth D, Prajkta C. Nanosuspension: novel techniques in drug delivery system. World J Pharm Pharm Sci 2014;3:410-33.

2. Shilpa CP. Nanosuspension-a novel approaches in drug delivery system. Int Pharm Res Rev 2013;2:30-9.

3. Bhowmik D. Nanosuspension-a novel approaches in drug delivery system. Pharma Innovation J 2013;1:50-63.
4. Harshil M Patel, Bhumi B Patel, Chainesh N Shah. Nanosuspension: a novel approach to enhance the solubility of poorly water-soluble drugs. Int J Adv Pharm 2016;2:21-9.

5. Muller RH, Jacobs C. Nanosuspension as a new approach for the formulation for the poorly water-soluble drug tarazepide. Int J Pharm 2000;196:161-4.

6. Chowdary KPR, Madhavi BLR. Novel drug delivery technologies for insoluble drugs. Ind Drugs 2005;42:557-63.

7. Kavitha VB, Neethu CS, Dineshkumar B, Krishnakumar K, Anish John. Nanosuspension formulation: an improved drug delivery system. Int J Nanosci Nanotech 2014;4:1-5.

8. Yadllohi R, Vasilev K, Simvoic S. Nanosuspension technologies for delivery of poorly soluble drugs. J Nanomat 2014;1-13. http://dx.doi.org/10.1155/2015/216375

9. Prasanna L, Giddam A. Nanosuspension technology. A Review. Int J Pharm Pharm Sci 2010;2:35-40.

10. Rupali L, Shashikant N, Nilesh K, Santosh L. A review nanosuspension. Int J Pharm Rev Res 2013;22:98-106.

11. Valsartan: Final text for addition to The International Pharmacopoeia, WHO; 2008. p. 1-5.

12. Madhusudan Y. Formulation and evaluation of poorly watersoluble drug Albendazole. Int J Pharm Pharm Sci 2017;2:11525.

13. Velmula M, Pavuluri P, Rajashekar S. A review-nanosuspension technology for poorly soluble drugs. World J Pharm Pharma Sci 2017;4:1612-25.

14. Kumar S, Singh P. An overview-varoius techniques for solubility enhancement. Pharma Innovation J 2016;5:23-8.

15. Singh DK, Tripathi K. Trigonella foenum-graecumas a potential hydrophilic carrier for the improvement of solubility and dissolution rate of curcumin. Int J Pharm Pharma Res 2016:6:156-61. 
16. Patel HB, Patel BB, C Shah. A review-nanosuspension: a novel approch to enhance the solubility of poorly water-soluble drugs. Int J Adv Pharma 2016;5:21-9.

17. Ghasemian E, Vahid R. Optimization of cefixime nanosuspension to improve drug dissolution. Pharm Sci 2015;21:136-44.

18. Yadollohi R, Vasilev K, Simovic S. A review-nanosuspension technologies for delivery of soluble drugs. J Nanomat 2015:113. http://dx.doi.org/10.1155/2015/216375

19. Agrawal V, Bajpai M. Preparation and optimization of Esomeprazole nanosuspension using evaporative precipitation ultrasonication. Trop J Pharm Res 2014;13:497-503.

20. Chandran S, Anandakirouchenane E. Enhancement of solubility of atorvastatin calcium by nanosuspension technique. Int J Biopharm 2014;5:214-7.

21. Danhier F, Bernard U. Nanosuspension for the delivery of a poorly soluble anti-cancer kinase inhibitor. Eur J Pharm Biopharm 2014;88:252-60.

22. Nandkumar Mane A, Sagar SG, Nikhil RB, Rohit RB. Nanosuspension-a novel carrier for lipidic drug transfer. Sch Acad J Pharm 2014;3:82-8.

23. Papdiwal A, Sagar K, Pande V. Formulation and characterization of Nateglinide nanosuspension by precipitation method. Int J Pharm Sci Nanotech 2014;7:2685-9.

24. Papdiwal A, Pande V, Sagar K. Design and characterization of zaltoprofen nanosuspension by precipitation method. Pharm Chem 2014;6:161-8.

25. Raju A, Jagdeesh R, Jithan AV. Preparation and characterization $f$ nevirapine oral nanosuspension. Ind J Pharm Sci 2014;76:62-71.

26. Rupali L Shid, Shashikant N Dhole, Nilesh Kulkarni, Santosh L Shid. Formulation and evaluation of nanosuspension formulation for drug delivery of simvastatin. Int J Pharm Sci Nanotech 2014;7:2650-65.

27. Singh VK, Singh P, Chandra D, Rai U, Kumar S, Singh P. Formulation and Evaluation of the effect of the different stabilizer at nanosuspension of Satranidazole. World J Pharm Pharm Sci 2014;2:1367-77.
28. Chaudhari B, Umesh K, Dhruv M. Preparation and evaluation of poorly soluble drug albendazole. J Drug Discovery Ther 2013;1:37-42.

29. Greeshma V Patel, Vaibhav B Patel, Abhishekh P. Nanosuspension for improved oral bioavailability: formulation optimization in vitro, in-situ and in vivo evaluation. Drug Dev Pharm 2013;40:80-91.

30. Prabhu SL, SP Sharavanan, S Govindaraju. Formulation and development of aceclofenac nanosuspension as an alternative approach for improving drug delivery of poorly soluble drugs. Int J Pharm Sci Nanotech 2013;6:2145-53.

31. Raturi A, Bhatt G, Kothiyal P. A review-formulation and evaluation of rosuvastatin calcium. Int J Pharm Rev Res 2014;3:42-51.

32. Kolhe S, Chipade M, Chaudhari PD. A review-nanosuspension of various techniques. World J Pharm Sci 2012;7:213-22.

33. RN Patel, Umashankar MS. Formulation and evaluation of nanosuspension containing erythromycin sterate. Am J Pharm Tech Res 2012;7:1062-80.

34. Patel M, Singh A, Patel NM. Nanosuspension a novel approach for drug delivery system. J Pharm Sci Biosci Res 2011;1:1-10.

35. Velmula VR, Lingala S. Solubility enhancement techniques. Int J Pharm Sci Rev Res 2010;5:41-51.

36. Rao S, GV Rao, Vardhan S, Ramachandran D. Development and validation of new UV-spectrophotometric assay method for valsartan in pure and in formulations. J Clin Pharm Res 2013;5:229-32

37. Geetha G, Poojitha U, Arshad Ahmed K. Various techniques for solubility enhancement. Int J Pharm Res Rev 2014;3:30-7.

38. Priti M, Ruchira C, Ujwala D. Lipid formulation classification. Int J Pharm Sci Rev Res 2012;1:118-23.

39. Bhanu S, Malay D. Nanosuspension for enhancement of oral bioavailability of felodipine. Appl Nanosci 2014;4:189-97.

40. Merin M, K Krishnakumar, B Dineshkumar, Smitha KN. A review article on antibiotics nanosuspension. J Drug Delivery Ther 2011;7:121-38. 